\title{
Effect of survivin downregulation by simvastatin on the growth and invasion of salivary adenoid cystic carcinoma
}

\author{
WEN-YAN CAI ${ }^{1}$, YING ZHUANG $^{2}$, FEI YAN ${ }^{3}$, TING LI $^{3}$, WEN-TING SONG ${ }^{3}$ and JIN-HU SUN ${ }^{3,4}$ \\ ${ }^{1}$ Department of Stomatology, Children's Hospital of Nanjing Medical University, Nanjing, Jiangsu 210008; \\ ${ }^{2}$ School of Pathology, Xuzhou Medical University; ${ }^{3}$ Department of Oral and Maxillofacial Surgery, \\ School of Stomatology, Xuzhou Medical University; ${ }^{4}$ Department of Stomatology, The Affiliated Hospital of \\ Xuzhou Medical University, Xuzhou, Jiangsu 221000, P.R. China
}

Received January 4, 2016; Accepted February 2, 2017

DOI: $10.3892 / \mathrm{mmr} .2018 .9204$

\begin{abstract}
Simvastatin, an inhibitor of 3-hydroxy-3methylglutaryl-coenzyme A reductase, is been used in the clinic due to its pleiotropic effects, such as breast cancer, prostate cancer, pancreatic cancer. Simvastatin has recently been demonstrated to serve a potential role in the prophylaxis and therapeutics of a number of human cancers. The majority of reports concerning simvastatin treatment in the majority of human cancers have demonstrated that survivin is significantly decreased as a result and has been implicated in tumorigenesis. However, only a limited number of studies have investigated the use of simvastatin for the treatment of salivary gland adenoid cystic carcinoma (SACC). Therefore, this agent is a candidate for further investigation. The aim of the present study was to investigate the effects of simvastatin on the proliferation, invasion and apoptosis of the human salivary adenoid cystic carcinoma cell line, SACC-83, as well as survivin expression in the cells. The Cell Counting kit- 8 assay results revealed that simvastatin inhibited the proliferation of SACC- 83 cells in a dose-dependent (10 to $50 \mu \mathrm{M})$ and time-dependent (24 to $48 \mathrm{~h}$ ) manner when compared with the untreated cells. Flow cytometry analysis indicated that simvastatin increased the percentage of cells in early and late apoptosis. Invasion assays revealed that simvastatin treatment inhibited the invasiveness of SACC-83 cells in a dose-dependent manner. In addition, simvastatin downregulated survivin expression in SACC-83 cells. In conclusion, simvastatin significantly inhibited the proliferation and invasion of SACC-83 cells, induced apoptosis,
\end{abstract}

Correspondence to: Professor Jin-Hu Sun, Department of Oral and Maxillofacial Surgery, School of Stomatology, Xuzhou Medical University, 209 Tongshan Road, Xuzhou, Jiangsu 221000, P.R. China E-mail: sjhjinhu@163.com; jinhu-sun@sohu.com

Abbreviations: SACC, salivary gland adenoid cystic carcinoma; MVA, mevalonate

Key words: simvastatin, salivary adenoid cystic carcinoma, growth, invasion, survivin and reduced the expression of survivin, which suggests that simvastatin may be a novel target for SACC therapy.

\section{Introduction}

Salivary gland adenoid cystic carcinoma (SACC) is one of the most common types of malignant tumor, and has unique clinical manifestations, as it is exclusively observed in the head and neck (1). It accounts for $\sim 10$ to $15 \%$ of salivary gland tumors. Pathologically, SACC is a basaloid tumor comprised of epithelial and myoepithelial cells in variable morphologic configurations, including tubular, cribriform and solid patterns $(2,3)$. It is characterized by the indolent yet persistent growth of salivary gland epithelium, perineural invasion, local recurrence and distant metastasis (4). The 5-year survival rate of patients with highly metastatic SACC is $<20 \%$. At present, surgical excision combined with postoperative radiotherapy is the routine treatment used $(5,6)$. However, the potent invasiveness and metastasis of SACC prevents complete eradication, which leads to poor prognosis and low survival rates. Therefore, novel approaches to treat SACC are required.

Simvastatin inhibits the rate-limiting step in the mevalonate (MVA) pathway and is applied clinically to reduce serum cholesterol levels and lower the incidence of cardiovascular and cerebrovascular events (7). In addition to its lipid-lowering effects, simvastatin is used to treat hypercholesterolemia, atherosclerosis, coronary heart disease and stroke $(8,9)$. However, simvastatin has additionally been demonstrated to inhibit tumor cell proliferation, promote apoptosis and suppress invasion via cholesterol-independent pleiotropic effects (10). The efficacy and molecular mechanisms underlying its actions in SACC-83 cells have not yet been fully elucidated.

Several oncogenes and tumor suppressor genes have been suggested to be involved in SACC (11). Survivin is overexpressed in a number of cancer types, including lung, prostate and Merkel cell carcinoma (12-15). Survivin overexpression in cancer patients is an unfavorable prognostic marker and is correlated with decreased survival in several malignancies $(16,17)$. In addition, overexpression of survivin is associated with an increased risk of recurrence, lymph node invasion and metastasis in cervical cancer, squamous cell cancer of the tongue, primary laryngeal carcinoma (18-20). In 
order to investigate the role of survivin in SACC cells treated with simvastatin in the present study, the human SACC cell line, SACC-83, was used to assess cell proliferation, apoptosis and survivin expression following simvastatin exposure.

\section{Materials and methods}

Cells, antibodies and reagents. The human SACC cell line, SACC-83, was provided by the Shanghai No. 9 People's Hospital (Shanghai, China). Simvastatin (Sigma-Aldrich; Merck KGaA, Darmstadt, Germany), the primary antibodies against survivin (cat. no. BS9870M; Biogot Technology Co., Ltd., Nanjing, China) and $\beta$-actin (cat. no. Ta-09; Beijing Zhongshan Golden Bridge Biotechnology Co., Ltd., Beijing, China) were commercial products.

Cell culture. Prior to the experiment, simvastatin was dissolved in anhydrous ethanol to obtain a final concentration of $2 \mu \mathrm{mol} / \mathrm{ml}$, followed by aseptic filtration and storage at $-20^{\circ} \mathrm{C}$ until the commencement of the experiment. SACC-83 cells were cultured in RPMI-1640 medium (Sigma-Aldrich; Merck KGaA) supplemented with $10 \%$ fetal bovine serum (FBS; Gibco; Thermo Fisher Scientific, Inc., Waltham, MA, USA), $100 \mathrm{mg} / \mathrm{ml}$ streptomycin and 100 units $/ \mathrm{ml}$ penicillin in a humidified atmosphere of $5 \% \mathrm{CO}_{2}$ and $37^{\circ} \mathrm{C}$. Cells were passaged when $90 \%$ confluent.

Cell proliferation assay. A Cell Counting Kit (CCK)-8 assay (Nanjing KeyGen Biotech Co., Ltd., Nanjing, China) was performed to determine cell proliferation in the logarithmic phase and to delineate a growth curve. SACC- 83 cells were plated at a density of $2 \times 10^{3}$ cells/well in 96-well plates and the outer wells were filled with sterile phosphate-buffered saline (PBS) which were cultured until adherence occurred. This was followed by treatment with simvastatin using a gradient of concentrations $(0,10,20,30,40$ and $50 \mu \mathrm{M})$ for 24 and $48 \mathrm{~h}$. CCK-8 solution $(10 \mu \mathrm{l})$ was subsequently added to each well of the 96-well plate, which was then incubated for $1 \mathrm{~h}$ at $37^{\circ} \mathrm{C}$. The optical density values were determined using an enzyme standard instrument set at an absorbance of $460 \mathrm{~nm}$ (BioTek Instruments, Inc., Winooski, VT, USA), and the half maximal inhibitory concentration $\left(\mathrm{IC}_{50}\right)$ was then calculated.

Colony forming assay. SACC- 83 cells were cultured at a density of 500 cells/well in 6 -well petri dish at $37^{\circ} \mathrm{C}$ in saturated humidity and $5 \% \mathrm{CO}_{2}$ for $48 \mathrm{~h}$. Following the removal of non-adherent cells, SACC-83 were cultured in the presence of simvastatin at varying concentrations $(0,10,20,30,40$ and $50 \mu \mathrm{M}$ ) in RPMI-1640 medium. Ten days following this, adherent cells were washed twice with PBS, followed by fixation with $4 \%$ paraformaldehyde for $10 \mathrm{~min}$ and $0.5 \%$ crystal violet staining at room temperature for $20 \mathrm{~min}$ to calculate colony counts.

Cell cycle analysis. SACC- 83 cells $\left(2 \times 10^{5}\right.$ cells/well) were seeded in six-well plates and treated with $50 \mu \mathrm{M}$ simvastatin for 24 and $48 \mathrm{~h}$. The cells were harvested, washed twice in PBS and fixed in $70 \%$ ice-cold ethanol at $4^{\circ} \mathrm{C}$ overnight. The cells were then centrifuged at 2,000 $\mathrm{xg}$ for $5 \mathrm{~min}$ at room temperature, washed twice in cold PBS and centrifuged again under the same conditions. Cells were suspended in $250 \mathrm{ml}$ PBS and staining with $10 \mathrm{ml}$ propidium iodide (Nanjing KeyGen Biotech Co., Ltd.) and $10 \mathrm{ml}$ RNase A (Nanjing KeyGen Biotech Co., Ltd.) for $30 \mathrm{~min}$ at room temperature. The proliferation index was defined as the proportion of cells in $\mathrm{S}$ and $\mathrm{G}_{1}$ phases from the total cell population. The cells in each group underwent flow cytometry (Facs Canto II, BD Biosciences) analysis to calculate the percentage of cells in $\mathrm{G}_{0} / \mathrm{G}_{1}, \mathrm{~S}$ and $\mathrm{G}_{2} / \mathrm{M}$ phases by FlowJo Diva (FlowJo LLC, Ashland, OR, USA).

Cell apoptosis analysis. SACC- 83 cells $\left(2 \times 10^{5}\right.$ cells/well) were seeded in 6-well plates and treated with simvastatin $(0,10,30$ and $50 \mu \mathrm{M}$ ) for $48 \mathrm{~h}$. Cells were then harvested and washed twice with PBS. Cells were subsequently resuspended with $500 \mu \mathrm{l}$ binding buffer (Nanjing KeyGen Biotech Co., Ltd.), and stained with $5 \mu \mathrm{l}$ PI (Nanjing KeyGen Biotech Co., Ltd.) and $5 \mu \mathrm{l}$ Annexin V-fluorescein isothiocyanate (Nanjing KeyGen Biotech Co., Ltd.) and incubated at room temperature for $10 \mathrm{~min}$ in the dark. In each group, $1 \times 10^{5}$ cells were analyzed by flow cytometry using BD FACSDiva version 8.0.1 software (Facs Canto II, BD Biosciences).

Western blot analysis. Total protein was separated by SDS-PAGE and western blotting was performed. Briefly, following treatment of cells with varying simvastatin concentrations $(0,10,20,30,40$ and $50 \mu \mathrm{M})$ for $48 \mathrm{~h}$ and following treatment with $50 \mu \mathrm{M}$ simvastatin for 24 , and $48 \mathrm{~h}$, each group were washed twice with cold PBS and collected at room temperature. Total protein was extracted using protein lysis solution containing RIPA buffer and $1 \%$ phenyl methane sulfonyluoride (PMSF; Beyotime Institute of Biotechnology, Haimen, China). Protein concentrations were measured using a BCA Protein assay kit (Beyotime Institute of Biotechnology). Followed by protein $(20 \mu \mathrm{g})$ separation on a $12.5 \%$ SDS-PAGE gel, proteins were then transferred to polyvinylidene difluoride membranes (Merck Millipore) for electrophoresis at a voltage of $60 \mathrm{~V}$ for $4 \mathrm{~h}$. Following this and blocking in 5\% nonfat dry milk for $2 \mathrm{~h}$ at room temperature, membranes were incubated with primary antibodies against survivin (cat. no. BS9870M; 1:1,000; Biogot Technology Co., Ltd., Nanjing, China) overnight at $4^{\circ} \mathrm{C}$. Subsequently, the blots were washed three times in PBS and incubated with a horseradish peroxidase-conjugated Goat anti-rabbit IgG (cat. no. ZB-2301; 1:5,000; Beijing Zhongshan Golden Bridge Biotechnology Co., Ltd.) for $2 \mathrm{~h}$ at room temperature. After washing three times, the membranes were immersed in BCIP/NBT alkaline phosphatase color development kit (C3206 Beyotime Institute of Biotechnology) for coloration and blots were quantified using ImageJ 1.49 software (National Institutes of Health, Bethesda, MD, USA).

Cell invasion assays. To assess the invasive capacity of simvastatin-treated cells, Matrigel invasion assays were performed. Pore filters $(8-\mathrm{mm})$ were inserted in 24-well plates (Sigma-Aldrich; Merck KGaA) coated with Matrigel (BD Biosciences, Franklin Lakes, NJ, USA) and the cells were then incubated with $0,10,30$ and $50 \mu \mathrm{M}$ simvastatin for $48 \mathrm{~h}$. Cells $\left(1 \times 10^{5}\right)$ were harvested and resuspended in RPMI-1640 medium containing $1 \%$ FBS, before they were added to the upper chambers and incubated for $24 \mathrm{~h}$ at $37^{\circ} \mathrm{C}$. Each lower chamber was filled with $500 \mu 1$ RPMI-1640 medium 
supplemented with $10 \%$ FBS. At the end of incubation, the non-invasive cells on the upper surface of the membrane were carefully removed using a cotton swab. The invaded cells on the lower surface of the membrane were fixed with $4 \%$ formaldehyde for $20 \mathrm{~min}$ and stained with $0.1 \%$ crystal violet for $5 \mathrm{~min}$ at room temperature. Subsequently, the invaded cells on the lower surface of the membrane were visualized in three randomly selected fields under a light microscope (Olympus BH-2; Olympus Corporation, Tokyo, Japan; magnification, $\mathrm{x} 200$ ). All assays were performed in triplicate, and the mean count of invaded cells was used for analysis.

Statistical analysis. Each experiment was conducted in triplicate. Statistical analysis was performed using SPSS 13.0 for Windows (SPSS, Inc., Chicago, IL, USA). Data are presented as the mean \pm standard deviation, and one-way analysis of variance and Dunnett's post-hoc tests were employed to determine statistically significant differences among groups. $\mathrm{P}<0.05$ was considered to indicate a statistically significant difference.

\section{Results}

Effect of simvastatin on the proliferation of SACC-83 cells As shown in Fig. 1, following treatment of cells with varying concentrations of simvastatin $(0,10,20,30,40$ and $50 \mu \mathrm{M})$ for 24 and $48 \mathrm{~h}$, the proliferation of SACC-83 cells was significantly inhibited in a time-(24 to $48 \mathrm{~h})$ and dose-dependent (10 to $50 \mu \mathrm{M})$ manner $(\mathrm{P}<0.05)$, whereas a modest level of inhibition was observed at concentrations $<10 \mu \mathrm{M}$ (data not shown). The $\mathrm{IC}_{50}$ value of simvastatin was $22.9 \mu \mathrm{M}$ at $48 \mathrm{~h}$, and the inhibitory rate at $50 \mu \mathrm{M}$ was $89.19 \pm 0.21 \%$ at $48 \mathrm{~h}$ (Fig. 1). Following treatment of cells with 0 to $50 \mu \mathrm{M}$ simvastatin, the colony forming ability of SACC-83 cells was significantly reduced at $20,30,40$ and $50 \mu \mathrm{M}$ concentrations, when compared with untreated controls $(\mathrm{P}<0.05$; Fig. 2$)$. These results demonstrated that simvastatin significantly suppressed the colonization of SACC-83 cells in a dose-dependent manner, indicating that simvastatin may inhibit the proliferation of SACC- 83 cells.

Effect of simvastatin on SACC-83 cell cycle and survivin expression. As simvastatin was demonstrated to inhibit the proliferation of SACC-83 cells, the effect of simvastatin on cell cycle distribution was subsequently investigated by flow cytometry analysis. As shown in Fig. 3, concomitant with its inhibition of the proliferation of SACC-83 cells, simvastatin treatment significantly induced cell cycle arrest in $G_{1}$ phase following incubation for 24 and $48 \mathrm{~h}$, with the percentage of cells in $G_{1}$ phase increasing from 52 to 62.1 and $66.2 \%$ at these time points, respectively $(\mathrm{P}<0.05)$. By contrast, the percentage of cells in $\mathrm{S}$ phase significantly decreased from 24.8 to $10.2 \%$ at $48 \mathrm{~h}$ following simvastatin treatment $(\mathrm{P}<0.05$; Fig. 3). A previous study demonstrated that survivin serves a key role in the regulation of cell proliferation, and is overexpressed during the $G_{2} / M$ phase and rapidly declines during $G_{1}$ phase (21). Following treatment of cells with varying simvastatin concentrations for $48 \mathrm{~h}$ and following treatment with $50 \mu \mathrm{M}$ simvastatin for 24 , and $48 \mathrm{~h}$, survivin expression was significantly reduced when compared with untreated controls (Fig. 4). By contrast, survivin was expressed at high levels in

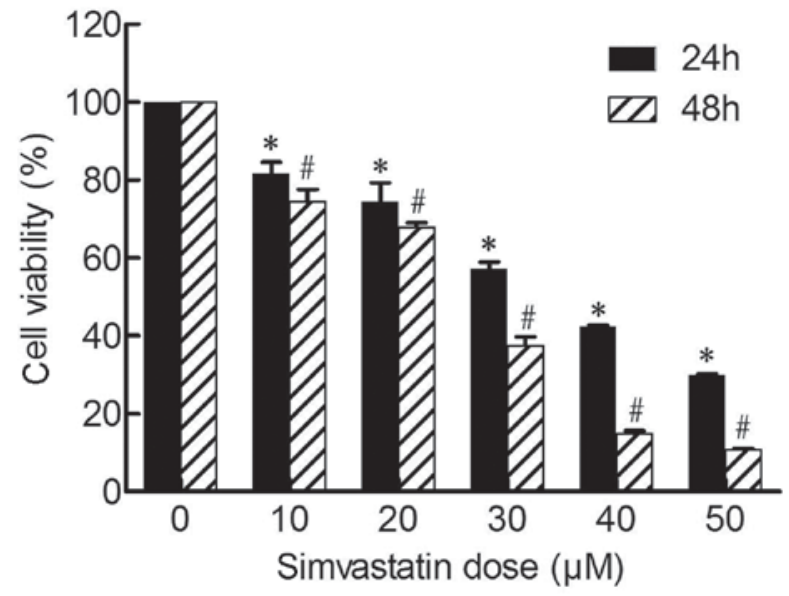

Figure 1. Simvastatin reduced the viability of SACC-83 cells. Cells were treated with varying concentrations of simvastatin $(0,10,20,30$, $40,50 \mu \mathrm{M}$ ) for 24 and $48 \mathrm{~h}$, and viability was determined using the Cell Counting Kit- 8 assay. The graph shows the percentage of viable cells in the simvastatin-treated group relative to the untreated control group. Data are presented as the mean \pm standard deviation of three independent experiments. ${ }^{*} \mathrm{P}<0.05$ vs. $0 \mu \mathrm{M}$ simvastatin control at $24 \mathrm{~h} ;{ }^{\#} \mathrm{P}<0.05$ vs. $0 \mu \mathrm{M}$ simvastatin control at $48 \mathrm{~h}$

A

$0 \mu \mathrm{M}$
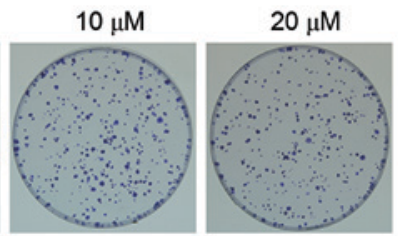

$30 \mu \mathrm{M}$ $40 \mu \mathrm{M}$ $50 \mu \mathrm{M}$
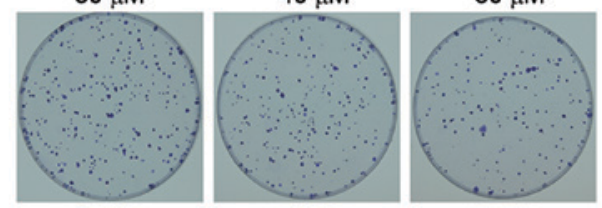

B

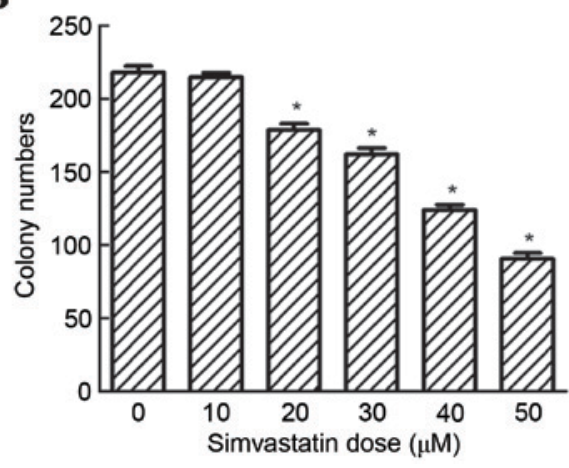

Figure 2. Simvastatin suppressed the clonogenicity of SACC-83 salivary gland adenoid cystic carcinoma cells in vitro. (A) Representative images of colony formation following exposure of SACC-83 cells to $0,10,20$, 30, 40 and $50 \mu \mathrm{M}$ simvastatin. (B) Quantification of colony numbers in each group. Data are presented as the mean \pm standard deviation of at least three independent experiments performed in triplicate. ${ }^{*} \mathrm{P}<0.05$ vs. $0 \mu \mathrm{M}$ simvastatin.

untreated SACC-83 cells (Fig. 4). These results suggest that simvastatin may mediate $\mathrm{G}_{1}$ phase arrest of SACC- 83 cells, in part, via a survivin-mediated pathway. 

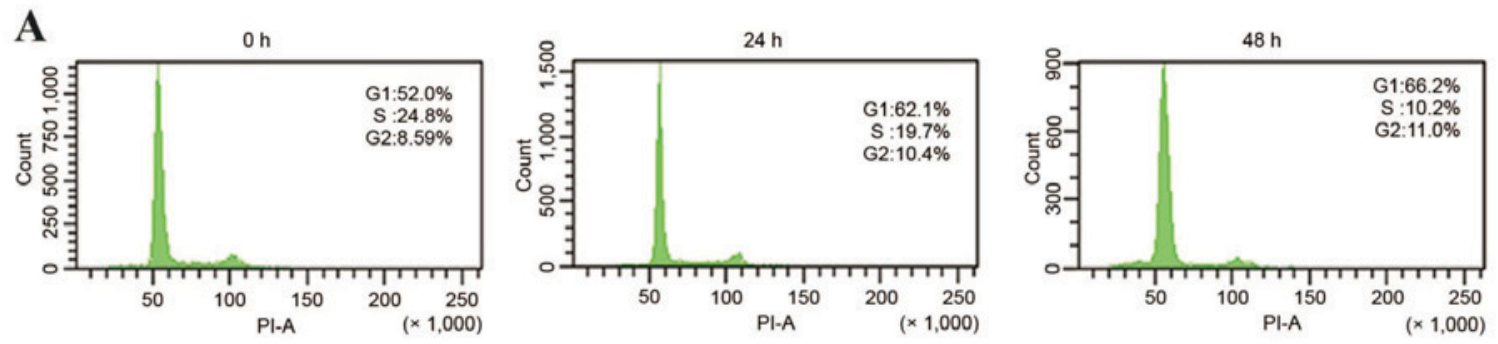

B

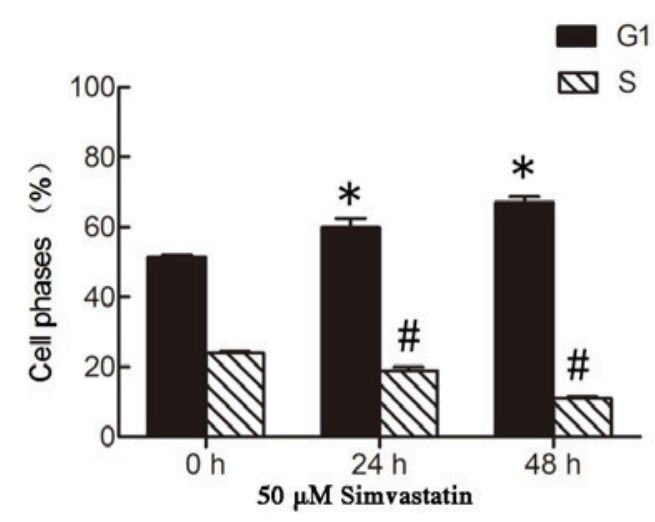

Figure 3. Cell cycle analysis of SACC-83 cells treated with $50 \mu \mathrm{M}$ simvastatin for 24 and $48 \mathrm{~h}$. (A) The number of cells in each cell cycle phase was measured by flow cytometry analysis. (B) The percentage of cells in $\mathrm{G}_{1}$ and $\mathrm{S}$ phases. Data are presented as the mean \pm standard deviation. ${ }^{\text {" }} \mathrm{P}<0.05$ vs. $\mathrm{G}_{1}-$ phase cells at $0 \mathrm{~h} ;{ }^{\#} \mathrm{P}<0.05$ vs. S-phase cells at $0 \mathrm{~h}$. PI, propidium iodide.
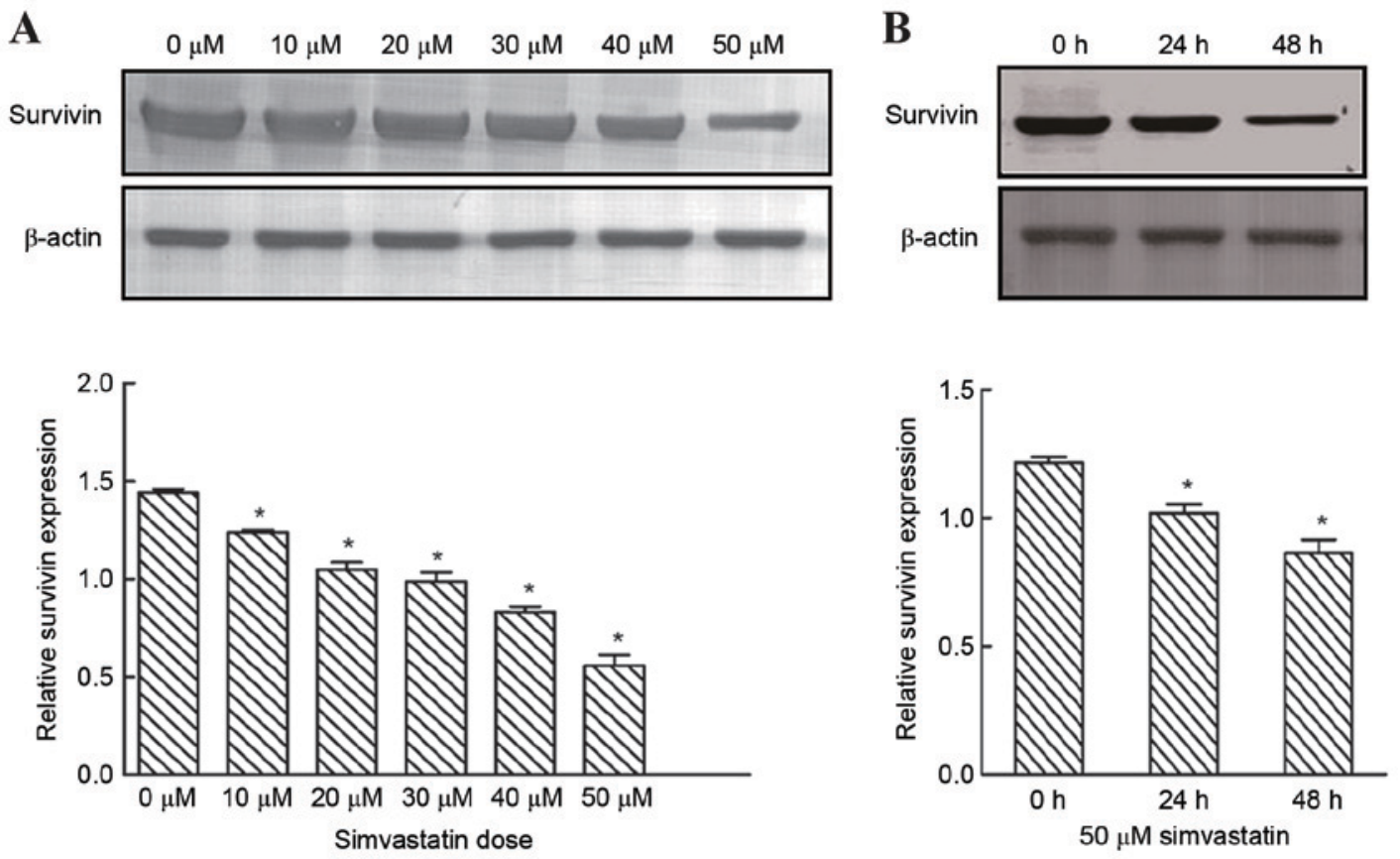

Figure 4. Expression of survivin in SACC cells. Western blot analysis of survivin expression in SACC-83 cells following (A) treatment with simvastatin at concentrations of $0,10,20,30,40$ and $50 \mu \mathrm{M}\left({ }^{*} \mathrm{P}<0.05\right.$ vs. $0 \mu \mathrm{M}$ simvastatin) and (B) simvastatin treatment at $50 \mu \mathrm{m}$ for 0,24 and $48 \mathrm{~h}(" \mathrm{P}<0.05$ vs. $0 \mathrm{~h}$ time-point). The relative survivin level indicates the density ratio of survivin $(16 \mathrm{kDa}) \mathrm{vs}$. $\beta$-actin $(36 \mathrm{kDa})$ expression. Data are presented as the mean \pm standard deviation. SACC, salivary gland adenoid cystic carcinoma.

Effect of simvastatin on SACC-83 cell apoptosis. Flow cytometry analysis was performed to evaluate the effect of simvastatin on cell apoptosis. Simvastatin at concentrations of $0,10,30$ and $50 \mu \mathrm{M}$ increased the percentage of apoptotic cells to $8.63 \pm 4.93,21.43 \pm 5.43,42.80 \pm 10.08$ and $67.97 \pm 12.50 \%$, respectively, following $48 \mathrm{~h}$ of exposure in early and late apoptotic cells ( $\mathrm{P}<0.05$; Fig. 5). By contrast, lower concentrations of simvastatin $(10 \mu \mathrm{M})$ demonstrated no significant effects on the 
A
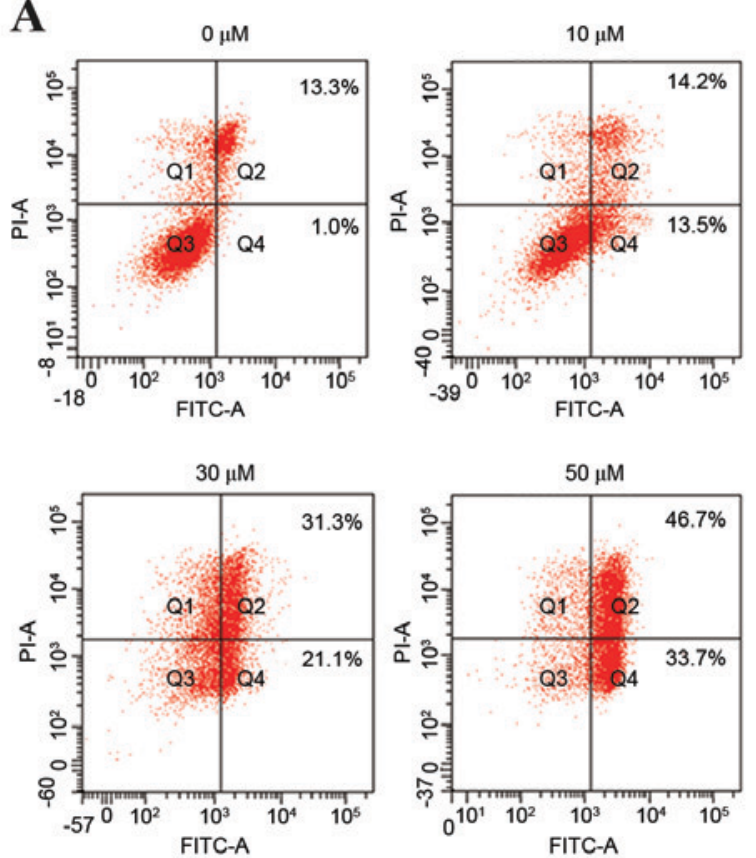

B

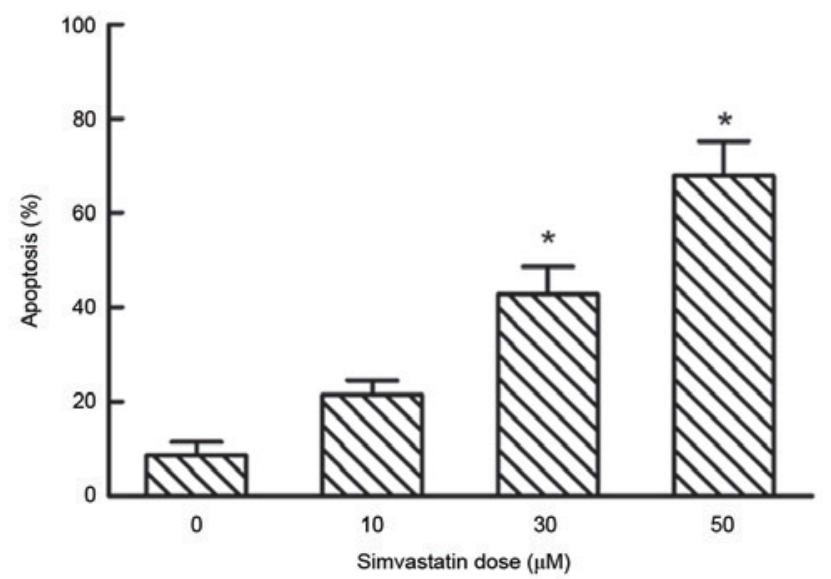

Figure 5. Simvastatin induced apoptosis of SACC-83 cells. (A) Flow cytometry analysis of cells (1x10 5 cells/sample) treated with simvastatin at concentrations of 0, 10, 30 and $50 \mu \mathrm{M}$ for $48 \mathrm{~h}$. Following treatment, cells were harvested and stained with Annexin V-FITC and PI. (B) The percentage of apoptotic cells in each treatment group. Data are presented as the mean \pm standard deviation. ${ }^{*} \mathrm{P}<0.05$ vs. $0 \mu \mathrm{M}$ simvastatin. FITC, fluorescein isothiocyanate; PI, propidium iodide.

number of apoptotic of SACC-83 cells when compared with untreated controls (10 $\mu \mathrm{M}, 21.34 \pm 5.43 \%$; Fig. 5).

Effects of simvastatin on the invasiveness of SACC-83 cells. The present study investigated whether simvastatin exposure affected the invasive capacity of SACC-83 cells. Treatment with varying concentrations of simvastatin $(0,10$, 30 and $50 \mu \mathrm{M})$ significantly suppressed the invasive ability of SACC-83 cells in a dose-dependent manner $(\mathrm{P}<0.05$; Fig. 6$)$. These results indicate the potency of simvastatin in inhibiting the invasiveness of SACC-83 cells.

\section{Discussion}

SACC develops in the major and minor salivary glands and is dispersed to the oral and oropharyngeal mucosa, tracheobronchial tree and the esophagus. At present, focal recurrence, distal metastases, or these outcomes together occur in the majority of patients (22), with 40 to $60 \%$ of SACC patients developing distant metastases in the lungs, bone and soft tissues (23). There is currently no available systemic therapy that effectively inhibits SACC progression. Therefore, the aim of current research is to identify strategies that target these refractory tumors.

Previous studies have demonstrated the potential of simvastatin in the treatment of human cancers $(10,24)$. Simvastatin competitively functions as a potent and specific inhibitor of 3-hydroxy-3-methylglutaryl-coenzyme A (HMG-CoA) reductase, and its use in clinical practice to treat hypercholesterolemia and hyperlipidemia is well established (7). An increasing number of studies have indicated that statins may improve the outcome of anti-cancer treatments (25-27). HMG-CoA reductase is involved in the transformation of
HMG-CoA into MVA. MVA, coupled with its downstream products, is involved in essential biological processes, including cell membrane composition (28-30), glycoprotein synthesis, intracellular signal transduction and cell cycle regulation. In addition, the MVA pathway has been implicated in tumorigenesis, including cell survival, proliferation, migration and invasion (31-33). In cancer patients, the suppression of genes involved in the MVA pathway is associated with favorable prognoses $(34,35)$. However, the mechanisms by which simvastatin downregulates the MVA pathway to activate apoptosis-associated signaling remains poorly understood. A previous study highlighted the critical role of the non-canonical regulation of Rho guanosine 5'-diphosphate hydrolases, and the involvement of the downstream superoxide-mediated activation of the c-Jun N-terminal kinase pathway in simvastatin-mediated anticancer activities $(10,36)$. Therefore, in addition to their lipid lowering, anti-inflammatory, antithrombotic and anti-oxidant properties, as a result of the involvement of HMG-CoA reductase in cholesterol synthesis and growth control, statins may demonstrate chemopreventative effects against cancer. However, the underlying molecular mechanisms remain unknown.

Survivin is an inhibitor of apoptosis proteins, and is overexpressed in malignant tumors and repressed in normal tissues. This suggests that survivin may be a novel target for tumor diagnosis, prognosis and anti-cancer therapies (16). In addition, survivin is a key factor in a number of cancers (37), and its gene encodes a multifunctional protein involved in the regulation of the cell cycle and inhibition of apoptosis pathways $(38,39)$. However, the role of survivin in regulating these processes is currently unclear. At the transcriptional level, survivin expression has been demonstrated to involve cell-cycle-dependent element/cell cycle gene homology region 
A

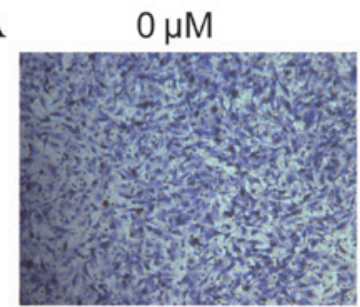

$30 \mu \mathrm{M}$

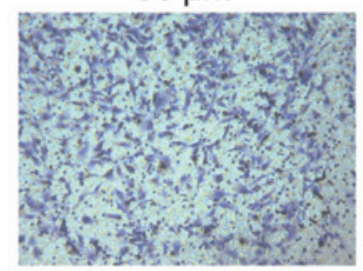

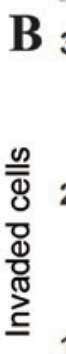

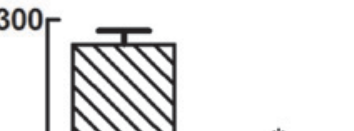

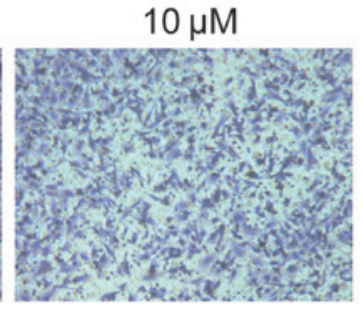

$50 \mu \mathrm{M}$
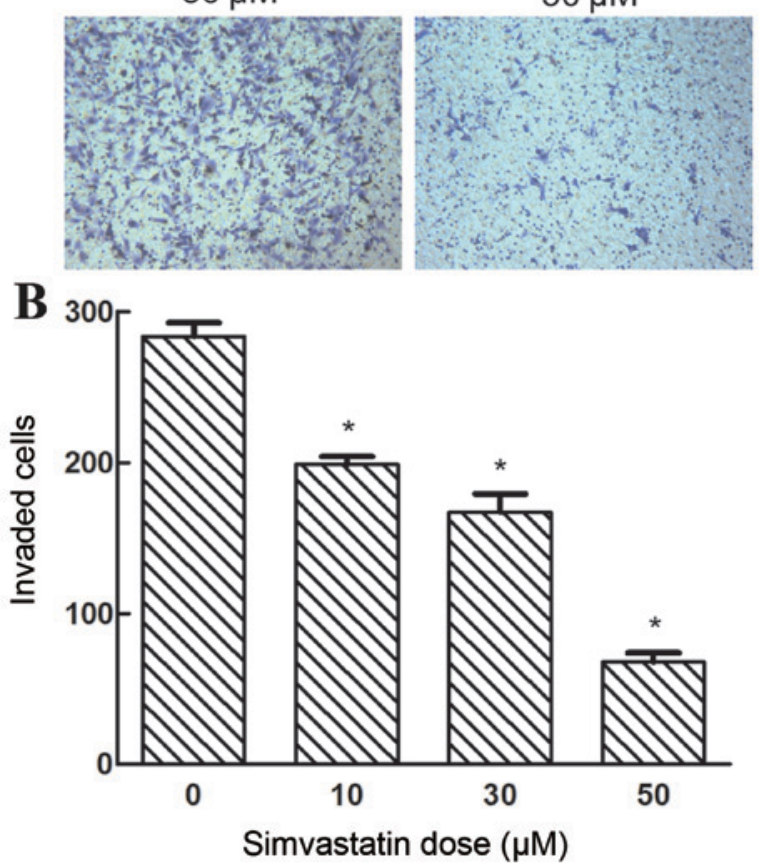

Figure 6. Simvastatin inhibited the invasive ability of SACC- 83 cells. Cells were incubated with simvastatin at concentrations of $0,10,30$ and $50 \mu \mathrm{M}$ for $48 \mathrm{~h}$. (A) Representative images of invaded cells at $48 \mathrm{~h}$ of invasion (magnification, x200). (B) Quantification of the number of invaded cells in each treatment group. Data are presented as the mean \pm standard deviation. ${ }^{*} \mathrm{P}<0.05$ vs. $0 \mu \mathrm{M}$ simvastatin.

G1 repressor elements in the baculoviral IAP repeat-containing 5 promoter (40).

The CCK-8 and colony-forming experiments performed in the present study demonstrated that simvastatin significantly inhibited the proliferation of SACC- 83 cells in a time- and concentration-dependent manner. Cancer cell proliferation is usually accompanied by cell cycle arrest, and cell cycle progression is modulated by cyclin-dependent kinase inhibitors $(41,42)$. In the present study, an increased number of SACC-83 cells were arrested at the $G_{1}$ phase following simvastatin treatment; however, further investigation is required to elucidate the underlying mechanisms involved. Cancer pathogenesis is associated with cell proliferation as well as abnormal apoptosis (43). Cell apoptosis is mediated by specific signaling molecules and controlled by the programmed process of cellular self-destruction, which is regulated by relevant genes (44). In the present study, simvastatin demonstrated the ability to induce apoptosis of SACC cells. Flow cytometry analysis revealed that, at $48 \mathrm{~h}$ post-simvastatin treatment, a significant increase in the rate of cell apoptosis was observed. Degradation of the extracellular matrix is crucial during cell invasion, and is usually mediated by extracellular proteases, notably matrix metalloproteinases (MMPs). Therefore, inhibition of MMPs may facilitate the prevention of the metastasis of cancerous cells (45). The mRNA and protein expression levels of MMPs have been reported to be reduced following exposure to increasing concentrations of simvastatin in squamous cells (46). Thus, simvastatin may reduce the expression of MMPs, which validates the inhibited invasion and metastasis of tumor cells. In the present study, simvastatin demonstrated a significant inhibitory effect on the invasive capability of SACC-83 cells, which may be attributable to its effect on MMP expression.

In the present study, simvastatin-induced apoptosis was characterized by the expression of survivin. A total of $68.4 \%$ in patients with SACC exhibit overexpression of survivin, and patients with negative survivin expression demonstrate significantly higher postoperative 5-year survival rates (47). In the present study, survivin expression decreased in a concentration-dependent manner following exposure of SACC- 83 cells to simvastatin. The results of previous studies indicate that survivin is closely associated with tumorigenesis and the prognosis of adenoid cystic carcinoma (AdCC) $(10,48)$. Therefore, targeting survivin may be an effective and novel approach to suppress the growth and improve the prognosis of $\mathrm{AdCC}$, which is consistent with the results of previous studies. Altered survivin expression may be directly implicated in the carcinogenic process, and due to its role in multiple cellular networks, survivin has been extensively studied as a potential anti-cancer drug target (49). In addition, reduced survivin expression reportedly serves a crucial role in lovastatin-induced apoptosis of SW480 colon cancer cells. Simvastatin induces apoptosis via survivin downregulation (50), and may activate specific signaling cascades to downregulate survivin expression by transcriptional, post-transcriptional or post-translational mechanisms $(51,52)$. In addition, the downregulation of survivin by simvastatin may be mediated by nuclear factor (NF)- $\mathrm{B}$ and additional transcription factors, such as hypoxia inducible factor- $1 \alpha$ and signal transducer and activator of transcription 3 , with simvastatin as an inhibitor of NF- $\kappa \mathrm{B}$-dependent anti-apoptotic gene expression (53). The authors of the present study hypothesize that simvastatin may be attributable to the downregulation of survivin expression. Therefore, further investigation is required to elucidate the potential effects of simvastatin on these transcription factors and/or their interactions.

In conclusion, the present study demonstrated that simvastatin inhibited the proliferation and invasion of SACC- 83 cells. In addition, survivin was downregulated during the process of simvastatin-induced apoptosis. These results support the current notions regarding the molecular mechanisms of SACC, and the use of survivin as a novel therapeutic target. The present study was performed in vitro; however, the results demonstrate the potential efficacy of simvastatin for the treatment of SACC, and may therefore support further extensive investigation into the efficacy of simvastatin as an antitumor agent.

\section{Acknowledgements}

The human SACC cell line, SACC-83, was provided by the Shanghai No. 9 People's Hospital. The present study was supported by the 'Qing Lan Project' of the Jiangsu Higher 
Education Institutions Young and Middle-aged Academic Leaders Funded Project (grant no. 51934) and the Outstanding Talent Fund Project of Xuzhou Medical College (grant no. 2013012).

\section{References}

1. van Weert S, Bloemena E, van der Waal I, de Bree R, Rietveld DH, Kuik JD and Leemans CR: Adenoid cystic carcinoma of the head and neck: A single-center analysis of 105 consecutive cases over a 30-year period. Oral Oncol 49: 824-829, 2013.

2. Moskaluk CA: Adenoid cystic carcinoma: Clinical and molecular features. Head Neck Pathol 7: 17-22, 2013.

3. Gondivkar SM, Gadbail AR, Chole R and Parikh RV: Adenoid cystic carcinoma: A rare clinical entity and literature review. Oral Oncol 47: 231-236, 2011.

4. Tang Y, Liang X, Zheng M, Zhu Z, Zhu G, Yang J and Chen Y: Expression of c-kit and Slug correlates with invasion and metastasis of salivary adenoid cystic carcinoma. Oral Oncol 46: 311-316, 2010.

5. Dodd RL and Slevin NJ: Salivary gland adenoid cystic carcinoma: A review of chemotherapy and molecular therapies. Oral Oncol 42: 759-769, 2006.

6. Laurie SA, Ho AL, Fury MG, Sherman E and Pfister DG: Systemic therapy in the management of metastatic or locally recurrent adenoid cystic carcinoma of the salivary glands: A systematic review. Lancet Oncol 12: 815-824, 2011.

7. Xu L, Li ZL, Zhao LY, Liu YF, Li GX, Ding MX, Zhao YQ, $\mathrm{Fu} \mathrm{Q}$ and Zhao X: Effects of simvastatin on DNA synthesis in rat cardiac fibroblasts. Nan Fang Yi Ke Da Xue Xue Bao 26: 205-207, 213, 2006 (In Chinese).

8. Kavalipati N, Shah J, Ramakrishan A and Vasnawala H: Pleiotropic effects of statins. Indian J Endocrinol Metab 19: 554-562, 2015

9. Chen W, Garcia JG and Jacobson JR: Integrin beta4 attenuates SHP-2 and MAPK signaling and reduces human lung endothelial inflammatory responses. J Cell Biochem 110: 718-724, 2010.

10. Zhu Y, Casey PJ, Kumar AP and Pervaiz S: Deciphering the signaling networks underlying simvastatin-induced apoptosis in human cancer cells: Evidence for non-canonical activation of RhoA and Rac1 GTPases. Cell Death Dis 4: e568, 2013.

11. Liu J, Shao C, Tan ML, Mu D, Ferris RL and Ha PK: Molecular biology of adenoid cystic carcinoma. Head Neck 34: 1665-1677, 2012.

12. Fukuda S and Pelus LM: Survivin, a cancer target with an emerging role in normal adult tissues. Mol Cancer Ther 5: 1087-1098, 2006.

13. Ko YH, Roh SY, Won HS, Jeon EK, Hong SH, Lee MA, Kang JH, Hong YS, Kim MS and Jung CK: Prognostic significance of nuclear survivin expression in resected adenoid cystic carcinoma of the head and neck. Head Neck Oncol 2: 30, 2010.

14. Dresang LR, Guastafierro A, Arora R, Normolle D, Chang Y and Moore PS: Response of Merkel cell polyomavirus-positive merkel cell carcinoma xenografts to a survivin inhibitor. PLoS One 8: e80543, 2013.

15. Falleni M, Pellegrini C, Marchetti A, Oprandi B, Buttitta F, Barassi F, Santambrogio L, Coggi G and Bosari S: Survivin gene expression in early-stage non-small cell lung cancer. J Pathol 200: 620-626, 2003.

16. Altieri DC: Survivin, versatile modulation of cell division and apoptosis in cancer. Oncogene 22: 8581-8589, 2003.

17. Schlette EJ, Medeiros LJ, Goy A, Lai R and Rassidakis GZ: Survivin expression predicts poorer prognosis in anaplastic large-cell lymphoma. J Clin Oncol 22: 1682-1688, 2004.

18. Kogo R, How C, Chaudary N, Bruce J, Shi W, Hill RP, Zahedi P, Yip KW and Liu FF: The microRNA-218 Survivin axis regulates migration, invasion, and lymph node metastasis in cervical cancer. Oncotarget 6: 1090-1100, 2015.

19. Doğan M, Çağl1 S, Yüce İ, Bayram A, Somdaş MA, Karataş D, Cihan MC, Yüksel F and Güney E: Survivin expression correlates with nodal metastasis in T1-T2 squamous cell carcinoma of the tongue. Eur Arch Otorhinolaryngol 272: 689-694, 2015.

20. Marioni G, Bertolin A, Giacomelli L, Marchese-Ragona R, Savastano M, Calgaro N, Marino F, De Filippis C and Staffieri A: Expression of the apoptosis inhibitor protein survivin in primary laryngeal carcinoma and cervical lymph node metastasis. Anticancer Res 26: 3813-3817, 2006.
21. Altieri DC and Marchisio PC: Survivin apoptosis: An interloper between cell death and cell proliferation in cancer. Lab Invest 79: 1327-1333, 1999.

22. Jaso J and Malhotra R: Adenoid cystic carcinoma. Arch Pathol Lab Med 135: 511-515, 2011.

23. Ding LC, Huang XY, Zheng FF, Xie J, She L, Feng Y, Su BH, Zheng DL and Lu YG: FZD2 inhibits the cell growth and migration of salivary adenoid cystic carcinomas. Oncol Rep 35: 1006-1012, 2016.

24. Turrell FK, Kerr EM, Gao M, Thorpe H, Doherty GJ, Cridge J, Shorthouse D, Speed A, Samarajiwa S, Hall BA, et al: Lung tumors with distinct p53 mutations respond similarly to p53 targeted therapy but exhibit genotype-specific statin sensitivity. Genes Dev: Aug 8, 2017 (Epub ahead of print).

25. Shimoyama S: Statins are logical candidates for overcoming limitations of targeting therapies on malignancy: Their potential application to gastrointestinal cancers. Cancer Chemother Pharmacol 67: 729-739, 2011

26. Matusewicz L, Meissner J, Toporkiewicz M and Sikorski AF: The effect of statins on cancer cells-review. Tumour Biol 36: 4889-4904, 2015.

27. Clendening JW and Penn LZ: Targeting tumor cell metabolism with statins. Oncogene 31: 4967-4978, 2012.

28. Clendening JW, Pandyra A, Boutros PC, El Ghamrasni S, Khosravi F, Trentin GA, Martirosyan A, Hakem A, Hakem R, Jurisica I and Penn LZ: Dysregulation of the mevalonate pathway promotes transformation. Proc Natl Acad Sci USA 107: 15051-15056, 2010.

29. Goldstein JL and Brown MS: Regulation of the mevalonate pathway. Nature 343: 425-430, 1990.

30. Nowakowski GS, Maurer MJ, Habermann TM, Ansell SM, Macon WR, Ristow KM, Allmer C, Slager SL, Witzig TE and Cerhan JR: Statin use and prognosis in patients with diffuse large B-cell lymphoma and follicular lymphoma in the rituximab era. J Clin Oncol 28: 412-417, 2010.

31. Mokarram P, Alizadeh J, Razban V, Barazeh M, Solomon C and Kavousipour S: Interconnection of estrogen/testosterone metabolism and mevalonate pathway in breast and prostate cancers. Curr Mol Pharmacol 10: 86-114, 2017

32. Ciaglia E, Grimaldi M, Abate M and Bifulco M: The isoprenoid derivative N6-benzyladenosine (CM223) exerts antitumor effect in glioma patient-derived primary cells through the mevalonate pathway. Br J Pharmacol 174: 2287-2301, 2017.

33. Shi J, Zhu J, Zhao H, Zhong C, Xu Z and Yao F: Mevalonate pathway is a therapeutic target in esophageal squamous cell carcinoma. Tumour Biol 34: 429-435, 2013.

34. Jiang P, Mukthavaram R, Chao Y, Nomura N, Bharati IS, Fogal V, Pastorino S, Teng D, Cong X, Pingle SC, et al: In vitro and in vivo anticancer effects of mevalonate pathway modulation on human cancer cells. Br J Cancer 111: 1562-1571, 2014.

35. Freed-Pastor WA, Mizuno H, Zhao X, Langerød A, Moon SH, Rodriguez-Barrueco R, Barsotti A, Chicas A, Li W, Polotskaia A, et al: Mutant p53 disrupts mammary tissue architecture via the mevalonate pathway. Cell 148: 244-258, 2012.

36. Stamatakis K, Cernuda-Morollón E, Hernández-Perera O and Pérez-Sala D: Isoprenylation of RhoB is necessary for its degradation. A novel determinant in the complex regulation of RhoB expression by the mevalonate pathway. J Biol Chem 277: 49389-49396, 2002.

37. Hwang KE, Na KS, Park DS, Choi KH, Kim BR, Shim H, Jeong ET and Kim HR: Apoptotic induction by simvastatin in human lung cancer A549 cells via Akt signaling dependent down-regulation of survivin. Invest New Drugs 29: 945-952, 2011.

38. Boidot R, Végran F and Lizard-Nacol S: Transcriptional regulation of the survivin gene. Mol Biol Rep 41: 233-240, 2014.

39. Salman T, Argon A, Kebat T, Vardar E, Erkan N and Alacacioğlu A: The prognostic significance of survivin expression in gallbladder carcinoma. APMIS 124: 633-638, 2016.

40. Jaiswal PK, Goel A and Mittal RD: Survivin: A molecular biomarker in cancer. Indian J Med Res 141: 389-397, 2015.

41. Lin S, Shang Z, Li S, Gao P, Zhang Y, Hou S, Qin P, Dong Z, Hu T and Chen P: Neddylation inhibitor MLN4924 induces G2 cell cycle arrest, DNA damage and sensitizes esophageal squamous cell carcinoma cells to cisplatin. Oncol Lett 15: 2583-2589, 2018.

42. Yu C, Cao H, He X, Sun P, Feng Y, Chen L and Gong H: Cyclin-dependent kinase inhibitor 3 (CDKN3) plays a critical role in prostate cancer via regulating cell cycle and DNA replication signaling. Biomed Pharmacother 96: 1109-1118, 2017.

43. Lara-Padilla E and Caceres-Cortes JR: On the nature of the tumor-initiating cell. Curr Stem Cell Res Ther 7: 26-35, 2012. 
44. Utz PJ and Anderson P: Life and death decisions: Regulation of apoptosis by proteolysis of signaling molecules. Cell Death Differ 7: 589-602, 2000.

45. Liu CC, Chang TC, Lin YT, Yu YL, Ko BS, Sung LY and Liou JY: Paracrine regulation of matrix metalloproteinases contributes to cancer cell invasion by hepatocellular carcinoma-secreted 14-3-3б. Oncotarget 7: 36988-36999, 2016.

46. Yu X, Pan Y, Ma H and Li W: Simvastatin inhibits proliferation and induces apoptosis in human lung cancer cells. Oncol Res 20: 351-357, 2013.

47. Wang YF, Ma SR, Wang WM, Huang CF, Zhao ZL, Liu B, Zhang WF, Zhao YF, Zhang L and Sun ZJ: Inhibition of survivin reduces HIF- $1 \alpha$, TGF- $\beta 1$ and TFE3 in salivary adenoid cystic carcinoma. PLoS One 9: e114051, 2014.

48. Farnebo L, Jerhammar F, Ceder R, Grafström RC, Vainikka L, Thunell L, Grénman R, Johansson AC and Roberg K: Combining factors on protein and gene level to predict radioresponse in head and neck cancer cell lines. J Oral Pathol Med 40: 739-746, 2011.

49. Tsuneki M, Kinjo T, Mori T, Yoshida A, Kuyama K, Ohira A, Miyagi T, Takahashi K, Kawai A, Chuman H, et al: Survivin: A novel marker and potential therapeutic target for human angiosarcoma. Cancer Sci 108: 2295-2305, 2017.
50. Chang HL, Chen CY, Hsu YF, Kuo WS, Ou G, Chiu PT, Huang YH and Hsu MJ: Simvastatin induced HCT116 colorectal cancer cell apoptosis through p38MAPK-p53-survivin signaling cascade. Biochim Biophys Acta 1830: 4053-4064, 2013.

51. Hisada T, Ayaori M, Ohrui N, Nakashima H, Nakaya K, Uto-Kondo H, Yakushiji E, Takiguchi S, Terao Y, Miyamoto Y, et al: Statin inhibits hypoxia-induced endothelin-1 via accelerated degradation of HIF-1 $\alpha$ in vascular smooth muscle cells. Cardiovasc Res 95: 251-259, 2012.

52. Hu D, Liu S, Shi L, Li C, Wu L and Fan Z: Cleavage of survivin by Granzyme M triggers degradation of the survivin-X-linked inhibitor of apoptosis protein (XIAP) complex to free caspase activity leading to cytolysis of target tumor cells. J Biol Chem 285: 18326-18335, 2010.

53. Wang YF, Ma SR, Wang WM, Huang CF, Zhao ZL, Liu B, Zhang WF, Zhao YF, Zhang L and Sun ZJ: Inhibition of survivin reduces HIF- $1 \alpha$, TGF- $\beta 1$ and TFE3 in salivary adenoid cystic carcinoma. PLoS One 9: e114051, 2014. International (CC BY-NC-ND 4.0) License. 